\title{
Customers Coping Strategies with Banks Automated Teller Machines (ATM) Service Failures
}

\author{
Donald O EWANLEN* \\ Department of Entrepreneurship and Marketing, Federal University Otuoke Bayelsa State Nigeria \\ PMB 126 Yenagoa Bayelsa State \\ Ifeanyi MADUMERE \\ Department of Accounting, Federal University Otuoke, Bayelsa State Nigeria \\ PMB 126 Yenagoa Bayelsa State
}

\begin{abstract}
This paper sought to identify incidence of Automatic Teller Machines (ATM) service failures and evaluated customers coping strategies. Primary data were collected with structured questionnaire from 200 respondents. Convenience sampling technique was adopted for sample collection. The collected data were analyzed with mean and standard deviation. The result shows that ATM inability to issue receipt was considered the highest indicator of service failure while $20 \%$ of the respondents choose not to take any action, $46 \%$ took only private action and $24 \%$ of the respondents applied a combination of these strategic options in dealing with ATM service failures. This paper therefore recommends that customers need adequate information about their rights and should appropriately demand for it, banks management should be alive to their responsibilities of delivery quality services while banks regulatory agencies should not hesitate to impose penalties on any erring bank that continually deliver substandard services to her customers.
\end{abstract}

Keywords: Automatic Teller Machines (ATM), Customers Coping Strategies, Ekpoma, Service Failure DOI: $10.7176 / \mathrm{EJBM} / 13-13-05$

Publication date:July $31^{\text {st }} 2021$

\section{Introduction}

Nigerian banks in the post consolidation era had to invest huge amount in the acquisition of modern Information Technology (IT) in their desire to satisfy customers' needs and retain them. The essence of this huge investment in IT is to expand the scope of banks service delivery, improve on the quality of service delivered and to emulate international best practices. To be able to achieve these objectives, several electronic payment options were introduced. Some of these payments alternatives include the electronic purse/wallets, mobile banking, internet/online banking, automatic teller machine, electronic funds transfer at point of sale, credit cards and debit cards. Appaih and John (2011) reported that automatic teller machine was customers most frequently adopted payment platform in Nigeria.

Marketing literature recognize customer satisfaction as a major driver of organizational performance. This implies that customer satisfaction as a primary outcome of marketing activity links decision making processes and consumption with post-purchase responses. According to Oliver(1980), as cited in Agbonifoh, Ogwo, Nnnolim and Nkamnebe (2006) customers' exhibit post purchase behaviour in the form of attitude change, complaining behavior, word of mouth communication, repeat purchase and brand loyalty. Although majority of organizations considers customer satisfaction as a cardinal objective, Ennew and Shoefer (2003) as cited in Agbonifoh et al (2006) posit that not all services from the customer's perspective are satisfactory. This suggests that service failures can and in fact do occur. Service failures are inevitable in every encounter between a customer and an organization. As expected the rate of service failure is high in a technologically driven process. This high rate of service failure is predicated on the unpredictability of technological devices. To the consumers, service failures results in negative disconfirmation. According to Smith and Bolton (2018), service failure has the capacity to initiate disappointing attitudes towards a service provider. These obvious discouraging encounters call for the development of strategies in handling these failures (Oxford, 2014). Tax, Brown and Chandrashekaran (1998) opine that following the frequent occurrence of service failures, it therefore become expedients for firms to devise strategies aimed at remedying the situation so as to ensure that customers are retained.

Notwithstanding the place of deployment of tactics to ameliorate poor service conditions, there are little or no sufficient researches intended to examine customers' reactions to a dissatisfactory service. It is however interesting to note that of recent several scholars have attempted to beam their search light on the aftermath of service failure and its attendant customers coping strategies. In spite of this, the connection between customers' reactions and service failure has not been explored (Tsarenko \& Strizhakova, 2013). This is the gap in literature that this study fills.

A review of extant literature reveals that several researches focus on the drivers of services in Nigeria. 
Adepoju and Mohammed (2010) study focuses on Automatic Teller Machine as a devise that facilitate occurrence of fraud in Nigeria. Also, Onyesolu, Asogwa and Chukwuneke (2016) study focused on ATM and customer traffic behavior in the eastern part of Nigeria. This paper sought to identify incidences of ATM service failures and evaluate strategies customers devise in coping with these service failures.

\section{Literature Review}

\section{Automatic Teller Machine}

The rapid growth in the banking sector globally has resulted in the deployment of Automatic Teller Machines (ATM). This massive deployment is driven by the introduction and diffusion of Information and Communication Technology ((ICT). ATM is a cash dispensing device that consists of a computer terminal, cash vault and record keeping system as one unit.

With the aid of a plastic card containing a Personal Identification Number (PIN) ATM customers can gain access to bank's book keeping system. Customers can make withdrawals by punching a special code number into the computer terminal linked to a bank's computerized records. A customer with an ATM card can carry out cash withdrawal, deposit cash, transfer money, pay utilities bills beyond official hours and without physical interaction with bank staff. Ultimately, the usage of ATM has revolutionized the practice of banking in Nigeria as it facilitates customers' quick and convenient access to their bank accounts (Adewuyi, 2011).

Steve (2002) remarked that ATMs are commonly found within banks premises and outside it where there are usually large gathering of people. Typically, ATMs were originally developed as cash dispensers. ATMs scope of operations has enlarge to such an extent that other bank related activities are now being performed. In countries that operate wholly integrated cross banking network, ATMs perform several activities that is not limited to paying routine bills, fees and taxes, printing bank statements, updating passbooks and loading monetary value into stored value card (Adewuyi, 2011).

Christolav, Marianne and Jeanne (2003) assert that the benefits derivable from ATM usage are so numerous. Some of these benefits include flexible access to accounts at customers convenience, little or no interface with banks personnel for successful transactions, increased hours of operation and as well as serving several customers even beyond normal banking hours. Despite the numerous benefits accrued to customers in their adoption of ATM as alternative payment option, Okechuckwu (2011) asserts that the major challenges in the operation of ATM in Nigeria include lack of adequate security, inadequate facilities, limited knowledge of services available, operational disruption, epileptic power supply and absence in the rural areas. Ogbuji,Onuoha, and Izogo (2012) study concludes that the emergence of ATM as a service delivery channel has not only increased the rate of bank fraud but equally increased the rate of financial indiscipline in Nigeria.

\section{Service Failure}

Of a truth service failure is inevitable in every transaction. The inevitability of service failure is traceable to the peculiarities involved in services production and consumption. Incidences of service failure irrespective of its magnitude often result in customer dissatisfaction and frustration. Consequently, customers in apparent state of despair are most likely to utter negative things about the service provider. The aftermath of such negative experiences hamper the firm's image and potentially turn other customers away.

Extant literature reveals that technological advancement and customers expectations are often the progenitors of service failure (Sengupta, Balaji, \& Krishnan, 2015). In this modern era, technological applications have assumed a unique position as it serves as a measure of customer and operations support. In fact, the level of a firm's technological deployment gives an indication of its operational efficiency and support. It therefore becomes necessary that managers pay attention to all the necessary resources that would enable the organization utilize these technological innovations maximally.

It is an acknowledged fact that customers expectations are evolving. Interestingly, these ever evolving customers' expectations are not restricted to a particular industry. In fact these expectations have evolved to the point where exceptional customer service is now considered the minimal. To address this every enlarging customer's expectations customized service in now becoming the trend in the marketplace. Customers' expectation borders now extend to providing solutions to both explicit customer requests and implicit needs. Arising from these many organization are now confronted with numerous obstacles in their bid to attain operational efficiency as well as success in delivery outstanding services.

\section{Indicators of ATM Service Failure}

Like in every interaction, customers' expectation in most cases often differs from actual performance. This difference from the customers' perspectives depicts service failure. Islam, Kumar, and Biswas (2007) study of ATM card holders' in Bangladesh identified insecurity, frequent breakdown of ATM and insufficient number of machines as predictors of ATM card holders' dissatisfaction. Similarly, Ahmadm and A1-Zu-bi (2011) qualitative study of Portuguese banks, reports that security and technical failures are determinants of customers' 


\section{dissatisfaction.}

In the same vein, Issahaku (2013) survey of ATM services in Ghana reveals that the probable causes of dissatisfaction range from customers are unable to withdraw cash beyond certain amount, poor network, the machine debiting a customer's account without dispensing cash. Others include double deduction of customer's account, the inability of ATM printer to issue receipt; and routine maintenance of ATM machines hence delay in operation. Also included are out of service and unable to dispense cash as the most prevalent problems that result in customers' dissatisfaction.

\section{Customers Coping Strategies}

Marketing literature is unanimous in recognizing customer coping strategies as personal effects made in seeking for remedy in addressing perceived service failure. These effects could be cognitive or behavioral in nature. This implies these effects are intended at monitoring both external and/or internal factors that leads to waste of resources (Lazarus, \& Folkman, 1984). However, Duhachek (2005) proposed active, expressive and avoidance as alternative classification of coping strategies. Active strategy is intended at resolving problems. Expressive strategy is targeted at offering solutions to all emotional issues as well as support seeking behaviours. Finally, avoidance is seen as the passive dismissal of a stressful problem. Furthermore, Sengupta, Balaji and Krishnan (2015) advocated taking no action, negative word of mouth; direct complaining to the service provider and complaining to a third party as strategies customers could adapt to deal with dissatisfactory services.

Day and Landon(1975) suggest that consumers of services are left with several options in dealing with dissatisfactory service. The options a customer is disposed to consist of take no action at all in the form of forget the experience. It also entails taking some form of action that consist of private action in the shape of brand switching, informing close friends and associates as well as public action such as seeking redress from the service providers, register a complaint with the service provider, a public complain commission or consumer protection agency or a private consumer organization. Finally, customers can also elect to utilize these options alone or in combination with other options. In sum, a customer's attempt at redressing the disappointing services received result in a situation where the customer is left with no option than to boycott the brand, inform others of their patronage experience or do nothing.

\section{Methods}

Survey methodology was adopted in this study. The population of study is the entire bank customers that holds a debit card in Ekpoma, Edo state Nigeria. Ekpoma is a semi urban town located in Edo central senatorial district. As a result of the semi urban nature of the town, traditional market days have a major influence on its commerce. In Ekpoma, there are on the average eight (8) traditional market days in a month. Also, in Ekpoma, there are eight (8) money deposit banks and a microfinance bank installed with cash dispensing machines. In this study, the researchers restricted their survey to holders of ATM debit cards in the eight (8) money deposit banks.

Questionnaire was distributed in all the money deposit banks in the town. Convenience sampling method was adopted in the selection of respondents. This method is predicated on the researchers' inability to obtain the actual population of customers with an ATM card in the locality. The questionnaire was self administered to the respondents in the eight bank premises during the traditional market days and Saturday of every weekend in the months of April and May 2019. The schedule of questionnaire administration was done in such a way that any bank previously visited on a weekend would not be visited on the weekend that collide with a market day. This precaution became necessary so as to ensure that all the banks were visited during the weekend (Saturday) and on a market day. The researchers choose to include the market days as a methodological issue in this study as the researchers' personal observations shows that majority of bank customers in Ekpoma seems to exhibit high demand for cash during this period as evident by the long queues in the banks. However, Two hundred (200) copies of questionnaire were administered and One hundred and eighty (180) retrieved, while one hundred and sixty (160) were found useable. This represents an eighty percent rate of return.

The research instrument is a structured questionnaire that consists of three sections. Section A contain questions on the respondents biographical data, section B is made up of questions on customers patronage experience with ATM services and section $\mathrm{C}$ shows the various coping techniques customers adopted in handling service failure. In section $\mathrm{B}$, respondents were expected to select the most appropriate answer that best reflect their usage experience using (VR) Very Rare (R) Rare, (U) neither Rare nor Often (O) Often (VO) Very Often. With respect to questionnaire items in section $\mathrm{C}$, customers were expected to respond using a Five point differential scale ranging from (1) very rare, (2) rare (3) Indifferent (4) often and (5) very often. Here, the respondents were to select the strategies adopted in coping with ATM service failure. This study adopted and modified Issahaku(2013) survey to identify the various incidences of ATM service failure while Day and Landon(1975) classification of coping strategies was used in evaluating customers coping strategies with ATM service failures.

The research instrument .was subjected to pilot test and both content and reliability tests .A reliability test 
with Cronbach alpha 0.83 indicates a good level of consistency of the instrument. The collated data were analyzed using mean scores and standard deviations were used to report on customers ATM patronage experience and coping strategies.

\section{Results/Discussions}

Objective one, Customer Experience with ATM Service Failures

Table 1: Mean and Standard Deviations of Customer Experience with ATM service failures

$\begin{array}{llcc}\text { Item } & \text { Incidence } & \text { Mean } & \text { Std. De } \\ \text { no. } & & 3.37 & 1.423 \\ 1 & \text { Long queue } & 3.55 & 1.053 \\ 2 & \text { Out of service } & 3.58 & 0.995 \\ 3 & \text { Temporarily unable to dispense cash } & 3.53 & 0.989 \\ 4 & \text { Card trapped } & 3.53 & 0.995 \\ 5 & \text { Dispensing worn out notes } & 3.56 & 1.028 \\ 6 & \text { Account debit without dispensing cash } & 3.52 & 1.015 \\ 7 & \text { Double debit my account } & 3.61 & 1.029 \\ 8 & \text { Service in progress, available shortly } & 3.58 & 1.068 \\ 9 & \text { Restriction on maximum daily withdrawals. } & 3.67 & 1.036 \\ 10 & \text { Issuer or switch inoperative } & 3.80 & 1.088 \\ 11 & \text { Idle service points in the midst of long queue } & 3.82 & 1.033 \\ 12 & \text { Printer is unable to print receipt }\end{array}$

Table 1 shows the mean scores and standard deviation of customers' experience of service failures in the patronage of ATM. Printers inability to print receipts report the highest (3.82) mean score. This is closely followed by idle service points (3.80) in the midst of long queues. On the other hand, the presence of long queues with a mean score of 3.37 the respondents considers as the least indicator of service failure. The findings of this study shows that the inabilities of ATMs printer to issue receipt is the most frequent. The desire of customers to obtain tangible evidence of transactions could possibly account for this finding. This is an affirmation of common banking practice where transactions are always acknowledged with a receipt. Equally important to the respondents is the incidence of idle services points in the midst of long queues. To the customers such incidence indicates insensitivity on the part of bank management in meeting the needs of customers. Finally, though quite unexpected respondents considers the existence of long queues as least indication of service failure. The most probable reason for this could be connected with the respondents' tolerance for the ever increasing bank customers that similarly request for ATM services.

Objective Two, Customers coping strategies with ATM service experiences

Strategic Option One: Take No Action

Table 2: Mean and Standard Deviation of Taking No action strategy

$\begin{array}{llll}\text { Item No. } & \text { Questionnaire item description } & \text { Mean } & \text { Std. Dev } \\ 1 & \text { It is not worth it } & 3.62 & .940 \\ 2 & \text { It would not make any difference. } & 3.65 & .911 \\ 3 & \text { I intended to complain but never did } & 3.65 & .905\end{array}$

Table 2 contains the mean scores and standard deviations of respondents no action coping strategy. The result shows that the average mean is 3.64. This represents a moderate score on a scale of 5. On the basis of standard deviation, there is a remarkable difference in the score. The score range from 0.905 to 0.940 . From this strategic option, the study reveals that the mean scores for all the activities were moderate. This portrays the respondents as pessimistic. Respondents' state of pessimism is an indication that customers are probably unaware of their right to demand for quality service. It is the contention of this paper that with better information about customers rights to fair and equitable service, customers' passive response towards service failure might lead to a reduction in the number of no action responses.

\section{Strategic Option Two: Take Action}

Table 3: Mean and Standard Deviation of Taking action strategy

$\begin{array}{llll}\text { Item No. } & \text { Questionnaire item description } & \text { Mean } & \text { Std. Dev } \\ 1 & \text { Switching to other ATM locations } & 3.62 & .940 \\ 2 & \text { Warning significant others. } & 3.65 & .911 \\ 3 & \text { Resorting to other payment options } & 3.65 & .905 \\ 4 & \text { Use of suggestion box. } & 3.76 & .990 \\ 5 & \text { Use of dedicated customer care numbers. } & 3.64 & .982 \\ 6 & \text { Use of written letters, emails messages and personal visits } & 3.69 & .931 \\ 7 & \text { Complaining to consumer protection agency or public } & 3.65 & .987\end{array}$

complain commission. 
From Table 3, the activity with the highest mean score (3.76) is the use of suggestion box while the least (3.62) is switching to other ATM locations. In fact, the mean score of all the actions are relatively close. The score range from 3.62 to 3.76. Similarly, the standard deviations of these actions are also closely related. The score vary from 0.905 to 0.990 . The findings of study suggest that the respondents that adopt this option prefer to take private action rather than public actions in the form of not complaining to customers' protection agency for instance. The possible explanation for this could be customers' belief that publicly seeking for redress is a mere waste of time and it is an exercise that ends in futility.

\section{Strategic Option Three: A Combination Strategy}

Table 4: Mean and Standard Deviations of combination strategy

\section{Item no Questionnaire item description}

$1 \quad$ It is not worth it.

$2 \quad$ It would not make any difference.

3 I intended to complain but never did

$4 \quad$ Switching to other ATM locations

$5 \quad$ Warning significant others.

$6 \quad$ Resorting to other payment options.

$7 \quad$ Use of suggestion box

8 Use of dedicated customer care numbers.

9 Use of written letters, emails messages and personal visits.

10

$\begin{array}{ll}\text { Mean } & \text { Std. Dev } \\ 3.67 & .990 \\ 3.69 & .951 \\ 3.65 & .954 \\ 3.97 & .994 \\ 3.84 & .983 \\ 3.79 & .951 \\ 3.55 & .977 \\ 3.68 & 1.023 \\ 3.64 & 1.065 \\ 3.83 & 1.042\end{array}$

As seen in Table 4, the mean scores of all the activities that the respondents employ to deal with ATM service failures are moderate on a scale of 5. Switching to other ATM locations scores the highest (3.97). The closest action is warning significant others with a 3.84 score. The activity with the least score is the use of suggestion box with a score of 3.55. On the basis of standard deviation, the activity with the highest variation is the use of written letters, emails and personal visits (1.062) while the least activity is customers' intention to complain but never did 0.951.The implication of these findings is that majority of the respondents prefers switching to other payment options. This is closely followed by informing significant others about the ATM service condition. The most probable reason for this would not be unconnected with customers' desires to settle their financial obligations in cash rather than embracing cashless transactions.

\section{Conclusion}

This paper examined customers coping strategies with ATM service failure. Service failure is a common experience in every transaction. Service failure occurs when the service providers are unable to meet customers' expectations. The extent of service failure is predicated on the medium of transaction. Literature acknowledges that technologically driven transactions are more prone to service failures. Extant literature remarks that services recovery strategies are often advocated from either the service providers or customers' perspectives. In this paper the researchers examined the various strategies customers would deploy to recover from a failed service. In particular, this study focused on take no action, take actions and a combination of both as strategies customers could devise to respond to incidences of ATM service failures.

The findings of this study reveals that $20 \%$ of the respondents took no action in handling instances of expressed dissatisfaction, $46 \%$ took actions though these actions were of a private nature, in the form of boycotting the supplier or warning friends while $34 \%$ of the respondents adopted a combination strategy in handling ATM service failures. This paper therefore concludes that customers need adequate information about their rights and should appropriately demand for it. Similarly banks management should be alive to their responsibilities of delivery quality services while banks regulatory agencies should not hesitate to impose penalties on any erring bank that continually deliver substandard services to her customers.

\section{Recommendations}

Flowing from the findings of this study, the researchers offer the following recommendations that;

(1) Customers should be encouraged to seek for more knowledge about their rights. This deliberate acquisition of relevant information confers confidence on the customers. It is the belief of the researchers that the acquired knowledge would equip the customers to demand for quality service.

(2) Bank management should adopt and practice the tenets as enunciated in customers' relationship management. It is expected when every customer is considered important enough to be retained it will reduce the incidence of brand switching.

(3) Banks regulatory agencies and in particular customers protection council in Nigeria could impose fines and levies on erring banks whose actions may appear to be insensitive to customers' needs. This paper suggest that these fines and levies should be imposed on banks that has a specific number of official complains of substandard services levied against them. Furthermore, banks regulatory agencies should therefore insist 
that such penalties must be reported in the bank's annual corporate governance accounts. It is expected that the imposition of such fines and levies would serve as a deterrent to other banks.

(4) We recommend that similar studies should be carried out with a larger sample size and geographical spread. This is with view of ascertaining the extent of generalization of these findings. The outcome of such a study could serve as a basis for the development of a comprehensive data base on the quality of ATM services.

\section{References}

Adepoju, A,S.; \& Mohammed, A.E.((2010) Challenges of Automated Teller Machine (ATM) usage and fraud Occurrences in Nigeria: A case study of selected banks in Minna Metropolis. Journal of Internet Banking and Commerce August, $10: 2$

Adewuyi , I.D (2011) Electronic Banking in Nigeria: Challenges to the regulatory authorities and the way forward.. International Journal of Economic Development Research and Investment 2(1): 32-45.

Agbonifoh, B.A, Ogwo. E. O, Nnnolim, D.O \& Nkamnebe, A.D. (2006) Marketing in Nigeria: Concepts, Principles \& Decisions Afritowers ltd: Aba.

Ahmadm A.M \& A1-Zu-bi (2011), e-banking functionality and outcomes of customer satisfaction::An Empirical Investigation. International Journal of Marketing Studies 3(1).: 31-47

Appaih E \& John S.M (2011): Merger and accusation in the Nigerian Banking industry: An Explorative Investigation. International Journal of Social Sciences, 5 (3): 67-89

Christolav E. A., Marianne A.H. \& Jeanne M. H. (2003). US Consumer's and electronic banking $1995-$ 2003.Board Division of Consumers and Community Affairs. Los Angeles

Day. R L. \& Landon , E. L. (1975),Survey data on consumer complaints for consumer Protection Policy Makers, Proceedings, Midwest AIDS Conference, 40-44.

Duhachek, A, (2005) Coping : A multidimensional, hierarchical framework of responses to stressful consumption episodes Journal of Consumer Research 32(June) 41-53

Ennew,D. \& Shoefer.P (2003) as cited in Agbonifoh, B.A, ,Ogwo. E. O, Nnnolim, D.O \& Nkamnebe, A.D. (2006) Marketing in Nigeria: Concepts, Principles \& Decisions Afritowers ltd: Aba.

Islam, R., Kumar, S.\& Biswas, P.K.(2007) Customer satisfaction of ATM service: A case study of HSBC ATM. http://papers.ssrn.Com/sol3/papers .cfm? abstract_id=990242 retrieved April 9, 2018

Issahaku, H (2013) Customers' experiences with ATM: A Comparative Analysis of GCB and Barclays bank ATM Services Advances in Agriculture, Sciences and Engineering Research:3 (3) Mar.: 724 - 734,

Lazarus, R.S. \& Folkman, S. (1984), Stress, Appraisal and Coping, Springer, New York, NY.

Ogbuji, C. N.,Onuoha, B. C \&Izogo E.E.(2012) Analysis of the negative effects of the Automated Teller Machine (ATM) as a Channel for Delivering Banking Services in Nigeria International Journal of Business and Management.7 (7) : 180-190

Okechuckwu N. (2011). Current Challenges' will Not Stop Cashless Economy implementationhttp://www.archive.punchontheweb.com/Articl.aspx?theartic... - Cached visited 04/02/2012

Oliver, R.L. (1980). A cognitive model of the antecedents and consequences of satisfaction decisions. Journal of Marketing Research, 17: 460-469.

Onyesolu1,M. O., Asogwa, D. C. \& Chukwuneke, C. I.(2016) Automated Teller Machine (ATM) and Customer Traffic Behaviour in Nigerian Banks: An investigative study International Journal of Emerging Technology and Advanced Engineering 6(1), January:1-6

Oxford (2014) Assimilation-Contrast Theory, Oxford Reference, Retrieved from: Perceived Product Performance, Journal of Marketing Research, 10, 38-44.

Sengupta, A. S., Balaji, M.S. \& Krishnan, B. C.( 2015) How customers cope with service failure? A Study of Brand Reputation and Customer Satisfaction Journal of Business Research 68:665-674

Smith, A. K. \& Bolton, R. N. (2018). The effect of customers' emotional responses to service failures on their recovery effort evaluations and satisfaction judgments. Journal of the Academy of Marketing Science, $39(4), 15-32$

Steve W. (2002) Automated Teller Machines; CGAP Staff and Exchange, CGAP IT Innovation Series: Los Angeles.

Tax, S. S., Brown, S. W. \& Chandrashekaran, M. (1998). Customer evaluations of service complaint experiences: Implications for relationship marketing. The Journal of Marketing,60-76.

Tsarenko, Y \& Strizhakova,Y(2013) Coping with service failures The role of emotional intelligence, selfefficacy and intention to complain European Journal of Marketing 47 (1/2,): 71-92 